\title{
PEMODELAN GAYA BERAT 3D DAERAH PANAS BUMI DOLOK MARAWA KABUPATEN SIMALUNGUN, SUMATERA UTARA 3D GRAVITY MODELING OF DOLOK MARAWA GEOTHERMAL FIELD IN SIMALUNGUN REGENCY, NORTH SUMATERA
}

\author{
Asep Sugianto dan Tony Rahadinata \\ Pusat Sumber Daya Geologi \\ Jl. Soekarno-Hatta No.444 Bandung \\ Email: asep.soegie@gmail.com
}

\section{SARI}

Daerah panas bumi Dolok Marawa merupakan salah satu daerah prospek panas bumi di Sumatera bagian utara. Daerah panas bumi tersebut berada pada zona patahan Sumatera dengan manifestasi permukaan berupa sekelompok mata air panas yang memiliki temperatur antara $37^{\circ} \mathrm{C}$ hingga $65^{\circ} \mathrm{C}$. Serangkaian survei gaya berat telah dilakukan di daerah ini pada tahun 2006 dan 2015. Sebanyak 257 data gaya berat telah diukur dari daerah ini, dengan cakupan luas pengukuran sekitar $16 \mathrm{~km} \times 13 \mathrm{~km}$. Penelitian ini bertujuan untuk mengetahui distribusi densitas batuan melalui pemodelan $3 \mathrm{D}$ pada data gaya berat dengan menggunakan perangkat lunak Grablox. Hasil pemodelan memperlihatkan suatu blok berdensitas rendah yang bentuknya berarah baratlaut-tenggara dan berimpit dengan zona patahan. Densitas batuan rendah tersebut bernilai sekitar $2,4 \mathrm{~g} / \mathrm{cm}^{3}$ dan dianggap sebagai batuan rekahan yang mengisi zona patahan. Hasil pemodelan juga memperlihatkan suatu blok berdensitas tinggi di bawah bukit Dolok Bahtopu. Blok densitas tinggi ini diinterpretasikan sebagai suatu tubuh intrusi andesitik dan mungkin bertindak sebagai sumber panas bagi sistem panas bumi Dolok Marawa.

Kata kunci : gaya berat, pemodelan 3D, panas bumi, Dolok Marawa, Sumatera

\section{ABSTRACT}

Dolok Marawa geothermal field is one of geothermal prospect areas in northern part of Sumatera and situated in the Sumatera Fault Zone. Surface thermal features consist of hot spring with temperature varies from $37^{\circ} \mathrm{C}$ to $65^{\circ} \mathrm{C}$. Series of gravity measurement had been conducted in the field in 2006 and 2015. The gravity data were measured from 257 stations covering an area of about $16 \mathrm{~km} \times 13 \mathrm{~km}$. This paper is aimed to identify rocks density distribution through 3-D gravity modeling by using Grablox modeling scheme. The model shows a pronounced low density block elongated at NW-SE direction, which coincides to the Sumatera fault lineament. Rock density of about $2.4 \mathrm{~g} / \mathrm{cm}^{3}$ of the low zone is considered to be associated to fractured rocks filling the fault zone. The model also shows high density block beneath Mt. Dolok Bahtopu. This high is interpreted as an andesitic intrusive body and considered as the heat source of the Dolok Marawa geothermal system.

Keywords : gravity, 3-D modeling, geothermal, Dolok Marawa, Sumatera

\section{PENDAHULUAN}

Sumatera merupakan salah satu pulau besar di Indonesia yang memiliki 93 lokasi panas bumi dengan total potensi sebesar 12.886 MWe status Maret 2015 (Anonim, 2015). Salah satu diantaranya adalah daerah panas bumi Dolok Marawa yang berada di 


\section{MAKALAH ILMIAH}

Kabupaten Simalungun, Sumatera Utara (Gambar 1). Daerah tersebut berada di sebelah timurlaut Danau Toba dan berada di sebelah tenggara lapangan panas bumi (PLTP) Sibayak. Secara geologi, daerah Dolok Marawa umumnya tersusun atas batuan yang berumur Kuarter berupa andesit, aliran dan jatuhan piroklastik. Struktur sesar yang berkembang di daerah tersebut berupa sesar normal yang berarah baratlaut-tenggara dan baratdaya-timurlaut (Gambar 2). Manifestasi panas bumi muncul berupa mata air panas dengan temperatur antara $37^{\circ} \mathrm{C}$ s.d $65^{\circ} \mathrm{C}$. Penelitian kepanasbumian yang meliputi metode geologi, geokimia, dan geofisika di daerah tersebut telah banyak dilakukan diantaranya oleh Setiawan, dkk (2006), Suryakusuma, dkk (2006), Zarkasyi, dkk (2006), dan Sundhoro, dkk (2006).

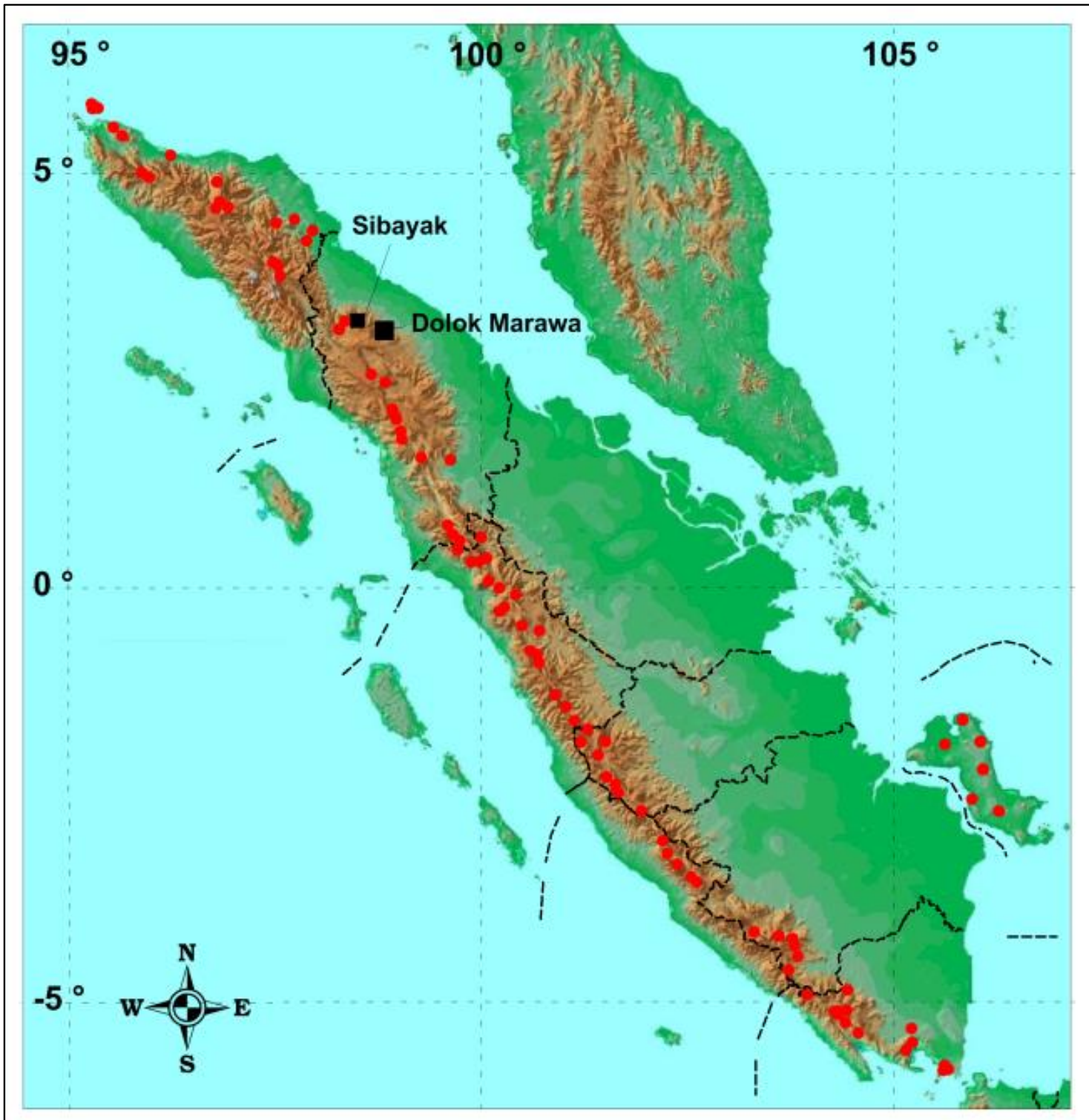

Gambar 1. Peta lokasi daerah panas bumi Dolok Marawa ( •lokasi daerah panas bumi lainnya di Pulau Sumatera ) 


\section{MAKALAH ILMIAH}

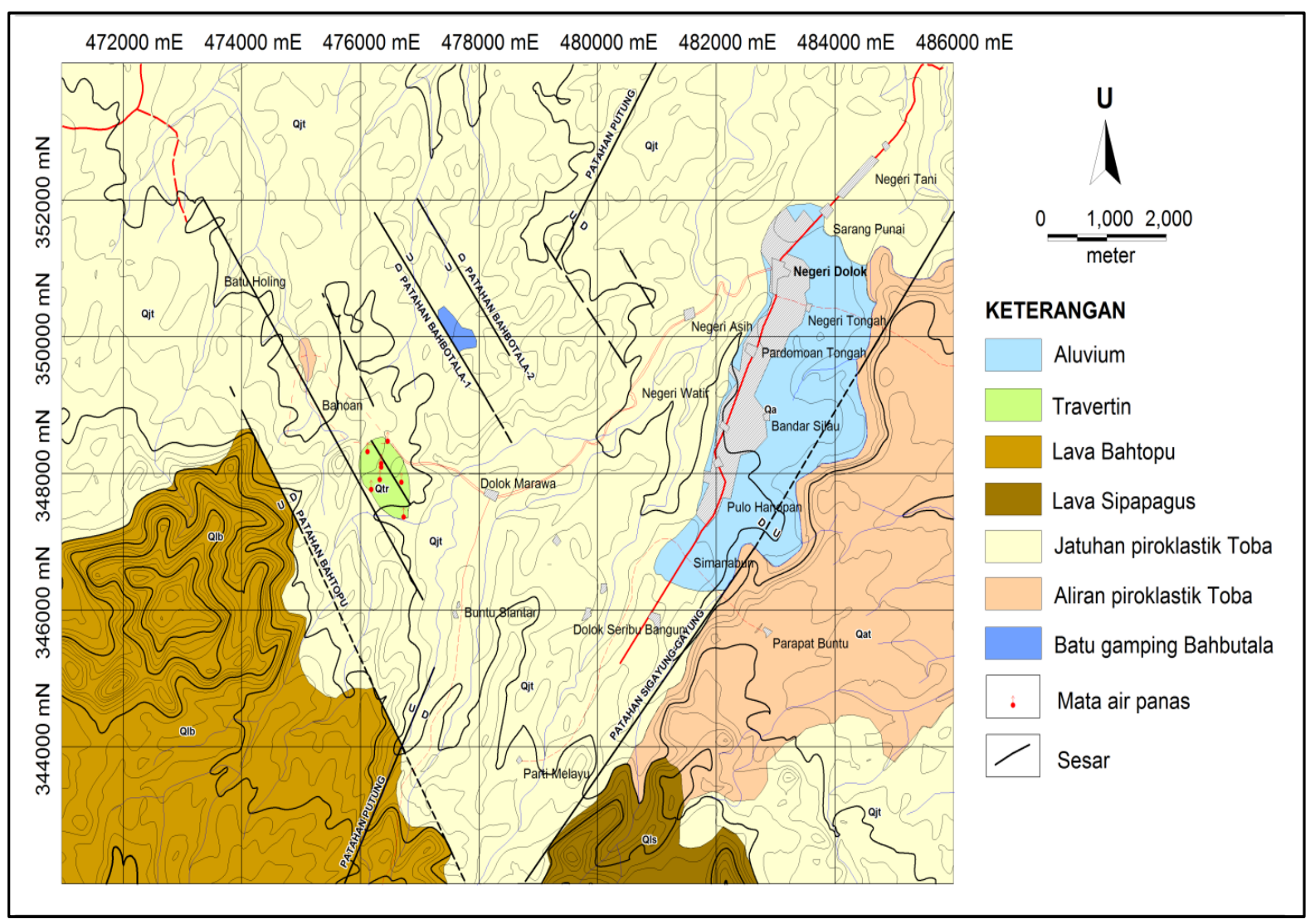

Gambar 2. Peta geologi daerah panas bumi Dolok Marawa

(modifikasi dari Setiawan, dkk. 2006)

Salah satu metode geofisika yang sering digunakan dalam survei panas bumi adalah metode gaya berat. Metode tersebut dapat digunakan untuk mengidentifikasi variasi densitas batuan dan struktur geologi di suatu daerah panas bumi (Santos, 2009). Selain itu, metode gaya berat juga dapat digunakan untuk mengindentifikasi sumber panas pada suatu sistem panas bumi (Tripp, 2002).

Pada makalah ini dibahas mengenai pemodelan 3D terhadap data gaya berat daerah panas bumi Dolok Marawa untuk mengetahui distribusi densitas batuan di bawah permukaan dari sistem panas bumi di daerah tersebut. Pemodelan 3D dilakukan dengan menggunakan program Grablox dari Pirttijärvi (2004). Program tersebut menggabungkan dua metode inversi, yaitu Singular Value Decomposition (SVD) dan inversi Occam (Hjelt, 1992). Hasil pemodelan dapat memberikan informasi mengenai variasi densitas batuan bawah permukaan dan dapat menggambarkan struktur sistem panas bumi di daerah ini.

\section{TINJAUAN DATA GAYA BERAT}

Pada penelitian ini digunakan data gaya berat pada 257 titik ukur yang tersebar secara acak dengan interval sekitar 500 meter (Gambar 3). Data gaya berat tersebut telah diambil oleh tim Pusat Sumber Daya Geologi pada tahun 2006 dan 2015. Pengolahan data meliputi koreksi udara bebas, koreksi Bouguer, dan koreksi medan. Pada koreksi Bouguer dan koreksi medan digunakan asumsi densitas batuan sebesar $2,4 \mathrm{~g} / \mathrm{cm}^{3}$ berdasarkan penentuan densitas dengan metode Parasnis (Gambar 4) dan analisis sampel batuan di laboratorium (Tabel 1) 


\section{MAKALAH ILMIAH}

Peta anomali Bouguer (Gambar 5) memperlihatkan adanya anomali tinggi $>8$ $\mathrm{mGal}$ di sebelah baratdaya sekitar Dolok Bahtopu yang diduga merupakan respon dari batuan andesit. Anomali sedang (1-7 mGal) terlihat di bagian tengah daerah survei, sedangkan anomali rendah $<1 \mathrm{mGal}$ berada di sebelah timur daerah survei. Anomali rendah dan sedang tersebut diperkirakan berasosiasi dengan aliran dan jatuhan piroklastik yang mendominasi daerah survei.

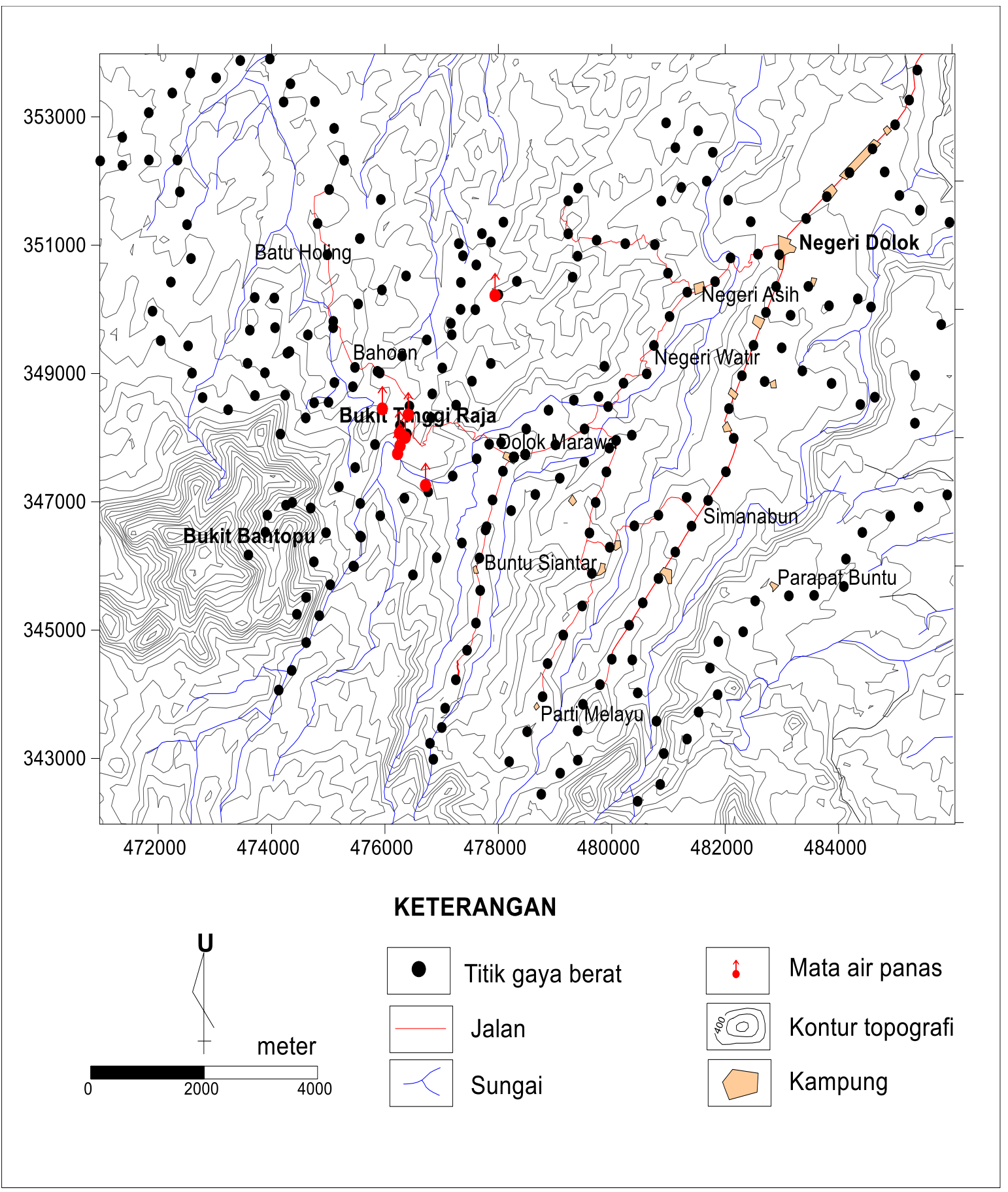

Gambar 3. Peta distribusi titik ukur gaya berat daerah panas bumi Dolok Marawa 


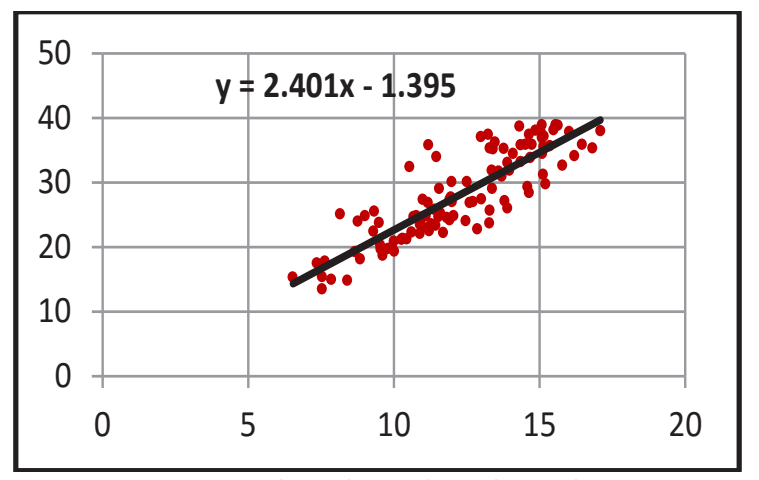

Gambar 4. Kurva penentuan densitas densitas dengan metode Parasnis

Tabel 1 Densitas Batuan Hasil Analisis di Laboratorium

\begin{tabular}{cccc}
\hline No. & Kode Conto & Nama Batuan & Densitas $\left(\mathbf{g} / \mathbf{c m}^{3}\right)$ \\
\hline 1 & DM-1 & Gamping Kristalin & 2,47 \\
\hline 2 & DM-4 & Tufa & 2,4 \\
\hline 3 & DM-2 & Andesit & 2,47 \\
\hline
\end{tabular}

Peta anomali regional ditentukan dengan menggunakan pendekatan polynomial orde 2. Peta tersebut memperlihatkan tren berarah hampir utaraselatan dengan anomali tinggi berada di sebelah barat dan anomali rendah berada di sebelah timur (Gambar 5).

Peta anomali residual (Gambar 5) memperlihatkan adanya anomali tinggi yang membentuk pola kontur tertutup di sekitar Dolok Bahtopu. Anomali tinggi dengan pola seperti itu mengindikasikan adanya tubuh batuan dengan densitas tinggi yang muncul hingga permukaan. Di sekitar sebaran mata air panas terlihat adanya distribusi anomali rendah yang diduga berasosiasi dengan zona rekahan akibat adanya struktur sesar yang berkembang di daerah tersebut.

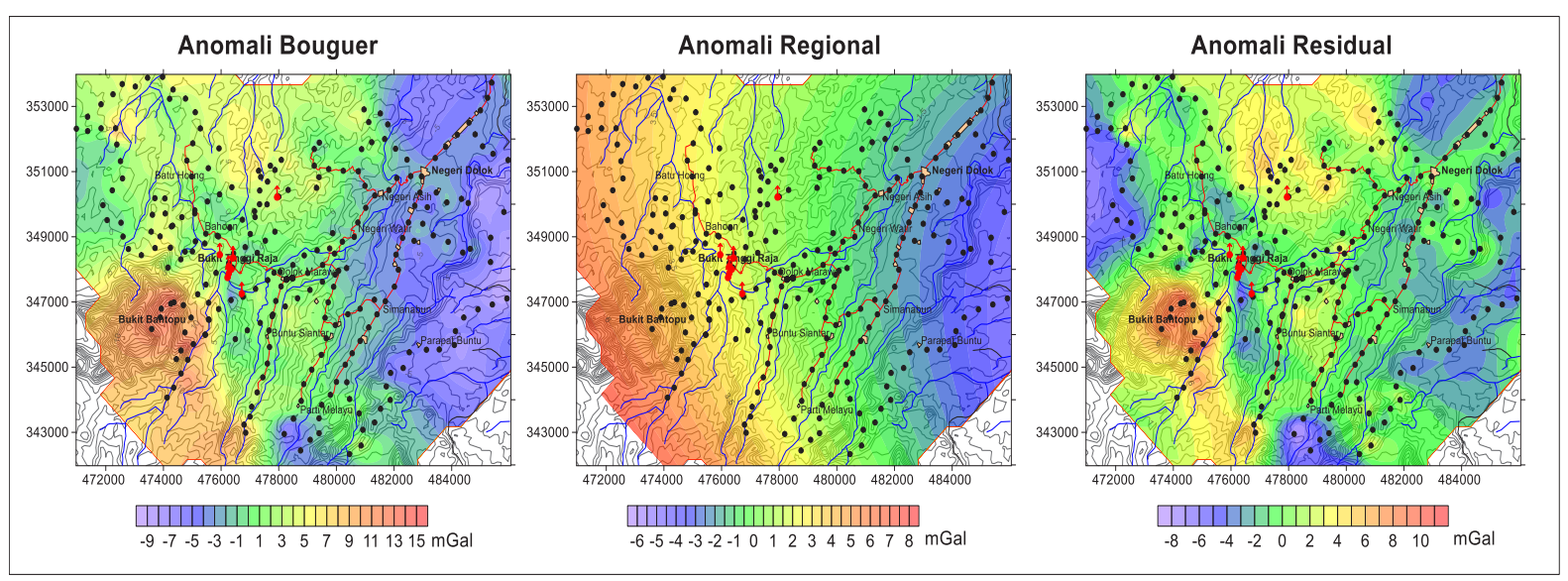

Gambar 5. Peta anomali Bouguer, anomali regional dan anomali residual

\section{METODE}

Pemodelan gaya berat 3D dilakukan dengan menggunakan program Grablox dari
Pirttijarvi (2004). Program tersebut menggabungkan dua metode inversi, yaitu Singular Value Decomposition (SVD) dan inversi Occam (Hjelt, 1992). Singular Value 


\section{MAKALAH ILMIAH}

Decomposition adalah suatu pemfaktoran matriks dengan mengurai matriks $\mathrm{A}$ ke dalam dua matriks $\mathrm{U}$ dan $\mathrm{V}$ (Zhao, 2011). Secara matematis dapat ditulis sebagai berikut:

$$
A=U S V^{\top}
$$

dimana $U$ adalah matriks orthogonal sebelah kiri, $S$ adalah suatu matriks diagonal atau singular value matrix, dan $\mathrm{V}$ adalah matriks orthogonal sebelah kanan. Inversi Occam adalah suatu metode inversi yang memanfaatkan tingkat kekasaran (roughness) model (Constable, 1987) yang secara matematis dapat ditulis sebagai berikut:

$U=\|\partial \mathbf{m}\|^{2}+\mu^{-1}\left\{\|\mathbf{W d}-\mathbf{W G m}\|^{2}-X_{*}^{2}\right\}$

dimana, $\quad\|\partial \mathrm{m}\|^{2}$ merupakan kekasaran (roughness), $\mu^{-1}$ adalah Lagrange multiplier, $\|\mathbf{W d}-\mathbf{W G m}\|^{2}$ adalah misfit, dan $X_{*}^{2}$ adalah error.
Pemodelan gaya berat difokuskan untuk mengetahui struktur bawah permukaan dari dekat permukaan hingga kedalaman, sehingga data yang digunakan sebagai input pemodelan adalah anomali Bouguer. Model awal dibuat berupa blok $16.500 \mathrm{~m} \times 13.000 \mathrm{~m} \times 3.000 \mathrm{~m}$ yang terbagi kedalam $33 \times 26$ sel dengan ukuran sel 500 $\mathrm{m} \times 500 \mathrm{~m}$ dan densitas awal sebesar 2,67 $\mathrm{g} / \mathrm{cm} 3$ (Gambar 6). Hasil pemodelan memperlihatkan RMS error sebesar 0,008 dan perbedaan antara data input (anomali Bouguer) dengan hasil perhitungan (inversi) yang kecil (Gambar 7).

Pemodelan geofisika (gaya berat) umumnya menghasilkan solusi yang tidak tunggal (Grandis, 2009). Karena itu, untuk mereduksi ketidak-unikan tersebut, maka hasil pemodelan gaya berat $3 \mathrm{D}$ ini diintegrasikan dengan data geologi dan dipilih model yang memberikan kesesuaian antara data observasi dengan data hasil perhitungan. 


\section{MAKALAH ILMIAH}

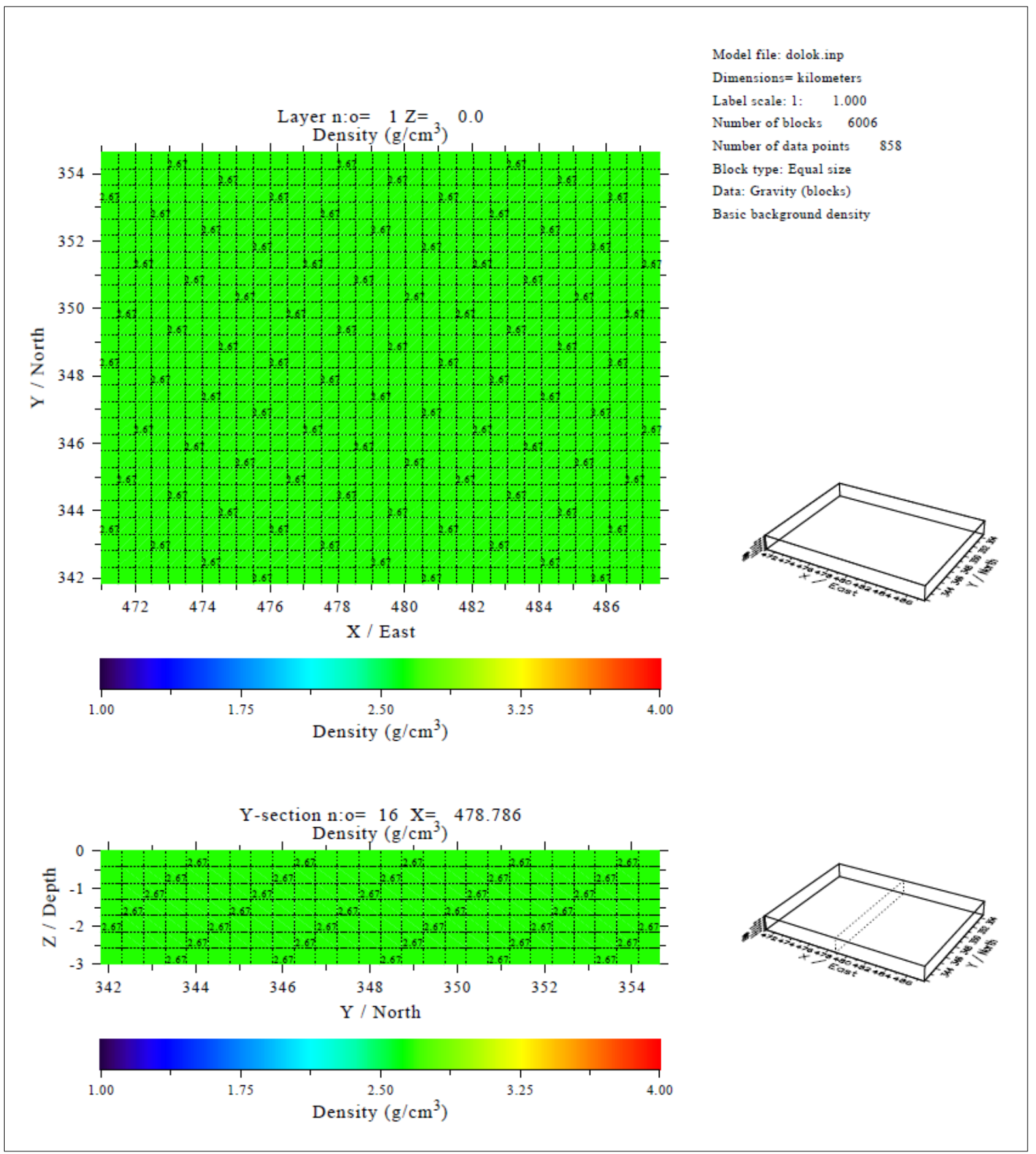

Gambar 6. Model awal yang digunakan dalam pemodelan gaya berat 3D 


\section{MAKALAH ILMIAH}

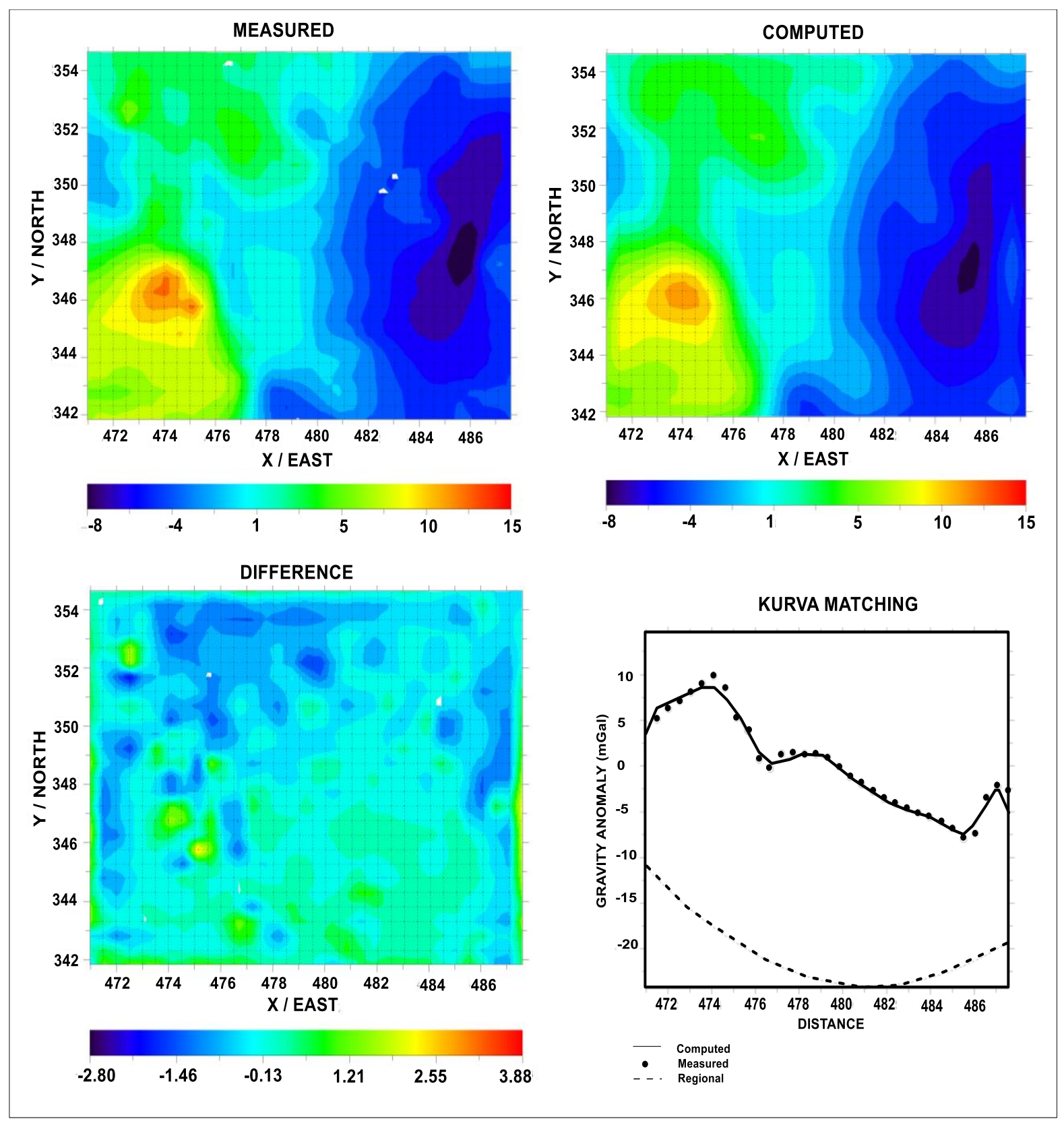

Gambar 7. Respon pemodelan gaya berat 3D daerah Dolok Marawa

\section{HASIL DAN PEMBAHASAN}

Hasil pemodelan ditampilkan dalam bentuk penampang dan peta distribusi densitas. Penampang model gaya berat merupakan gambaran densitas batuan secara vertikal hasil sayatan model 3D, sedangkan peta distribusi densitas batuan merupakan gambaran densitas batuan secara horizontal yang disayat dari hasil pemodelan 3D pada elevasi yang sama, yaitu elevasi $50 \mathrm{mdpl}$ dan $-550 \mathrm{mdpl}$.
Pada makalah ini disajikan 3 penampang dari hasil pemodelan gaya berat 3D. Penampang tersebut berarah barat-timur dengan mempertimbangkan keberadaan struktur sesar yang berarah baratlauttenggara sebagai pengontrol kemunculan manifestasi Tinggi Raja (Gambar 8).

Penampang 1 berada di utara dan melewati mata air panas Butala. Penampang 1 tersebut memperlihatkan distribusi batuan dengan densitas sedang $2,6 \mathrm{~g} / \mathrm{cm}^{3}$ di dekat permukaan dan distribusi batuan dengan 
densitas tinggi $>2,7 \mathrm{~g} / \mathrm{cm}^{3}$ di bagian bawah. Batuan dengan densitas sedang tersebut diduga sebagai jatuhan piroklastik Toba. Batuan dengan densitas sedang di sebelah barat dan timur terpisahkan oleh kemunculan batuan dengan densitas tinggi $2,7 \mathrm{~g} / \mathrm{cm}^{3} \mathrm{di}$ sekitar mata air panas Butala. Batuan dengan densitas tinggi di bagian bawah diinterpretasikan sebagai batuan dasar (metamorf). Kontras densitas batuan di sebelah barat mata air panas Butala mengindikasikan adanya struktur sesar yang membentuk suatu graben.

Penampang 2 berada di bagian tengah dan memotong mata air panas Tinggi Raja.
Pola distribusi densitas pada penampang 2 relatif sama dengan pola distribusi densitas pada penampang 1. Batuan dengan densitas sedang tersebar dari dekat permukaan hingga kedalaman sekitar $1500 \mathrm{~m}$. Batuan dengan densitas rendah terlihat di sebelah barat mata air panas Tinggi Raja dari dekat permukaan hingga kedalaman sekitar $500 \mathrm{~m}$. Batuan tersebut diduga sebagai piroklastik Toba dan/atau batuan vulkanik yang terkekarkan. Kontras nilai densitas sedang dan rendah $<2,5 \quad \mathrm{~g} / \mathrm{cm}^{3}$ yang mengindikasikan adanya struktur sesar terlihat di sebelah timur mata air panas Tinggi Raja.

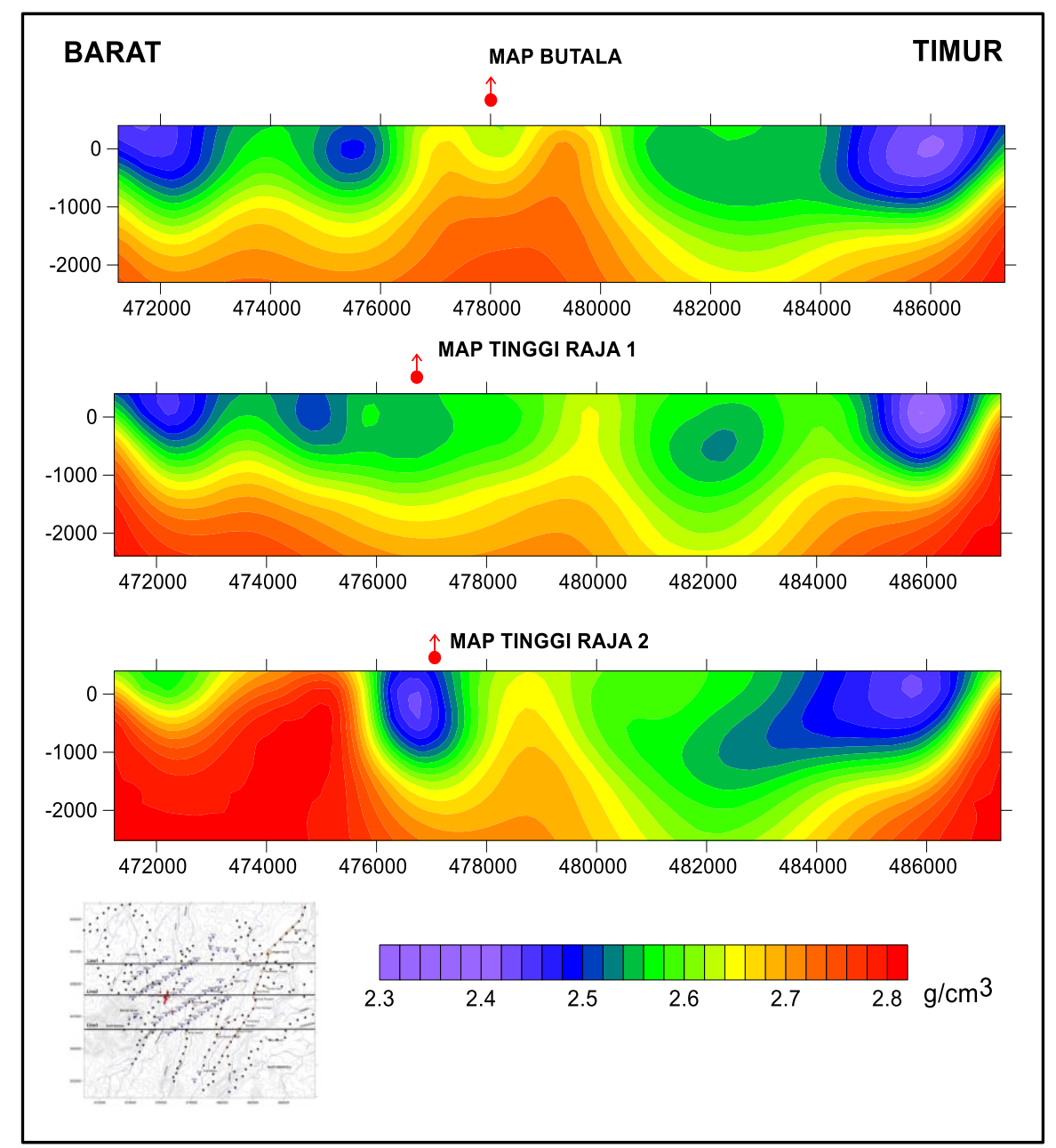

Gambar 8. Penampang model gaya berat daerah panas bumi Dolok Marawa;penampang 1 berada paling atas, penampang 2 di tengah, dan penampang 3 berada paling bawah

Penampang 3 berada di selatan dan memotong Dolok Bahtopu. Pada penampang ini tergambarkan tubuh Dolok Bahtopu yang dicirikan dengan nilai densitas tinggi 2.8 


\section{MAKALAH ILMIAH}

$\mathrm{g} / \mathrm{cm}^{3}$. Nilai densitas tinggi menerus dari dekat permukaan hinggai ke elevasi $2000 \mathrm{~m}$. Zona depresi yang dicirikan dengan kontras densitas terlihat di sekitar mata air panas Tinggi Raja. Zona depresi tersebut lebih sempit dibandingkan dengan zona depresi pada penampang 1 \& penampang 2

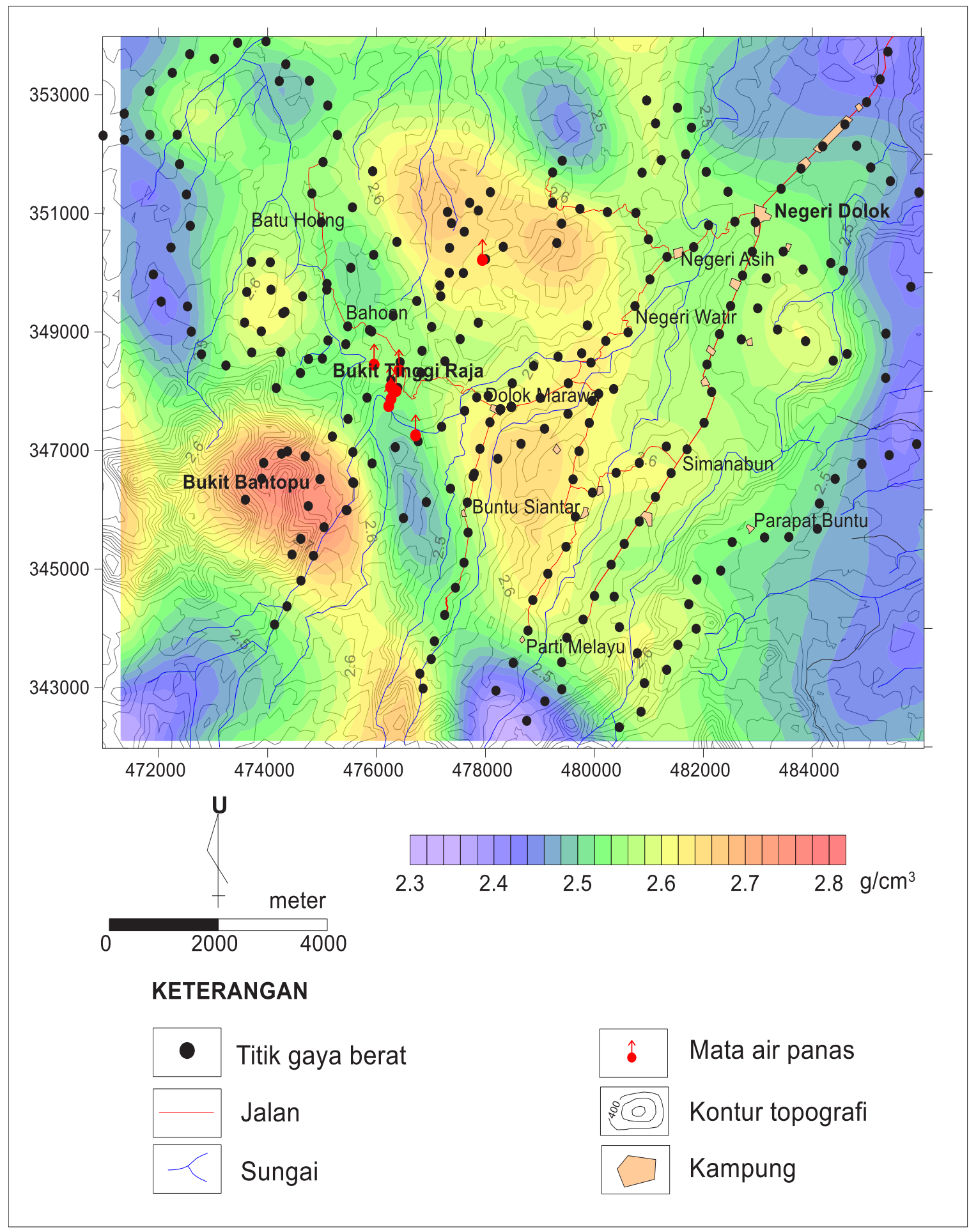

Gambar 9. Peta sebaran densitas elevasi 50 m daerah Dolok Marawa 


\section{MAKALAH ILMIAH}

Peta sebaran densitas pada elevasi 50 m (Gambar 9) secara umum memiliki pola hampir sama dengan peta anomali Bouguer residual (lihat Gambar 5). Batuan dengan densitas tinggi $\left(>2,7 \mathrm{~g} / \mathrm{cm}^{3}\right)$ berada di sebelah baratdaya yang diduga sebagai batuan vulkanik produk Dolok Bahtopu. Batuan dengan densitas rendah $\left(<2,4 \mathrm{~g} / \mathrm{cm}^{3}\right)$ berada di sebelah timur dan selatan yang diinterpretasikan sebagai piroklastik Toba (sebelah utara) dan lava Sipapagus (sebelah timur). Di sekitar mata air panas Tinggi Raja terdapat batuan dengan densitas $2.4 \mathrm{~g} / \mathrm{cm}^{3}$.
Batuan tersebut memanjang dari sebelah utara mata air panas Tinggi Raja hingga ke sebelah selatan yang diduga sebagai batuan ubahan dan zona rekahan.

Kontras nilai densitas tinggi dan rendah membentuk kelurusan berarah baratlaut-tenggara. Kelurusan tersebut berada di sebelah barat dan timur mata air panas Tinggi Raja membentuk suatu zona depresi. Selain itu, terdapat juga kontras densitas yang membentuk kelurusan berarah baratdaya-timurlaut.

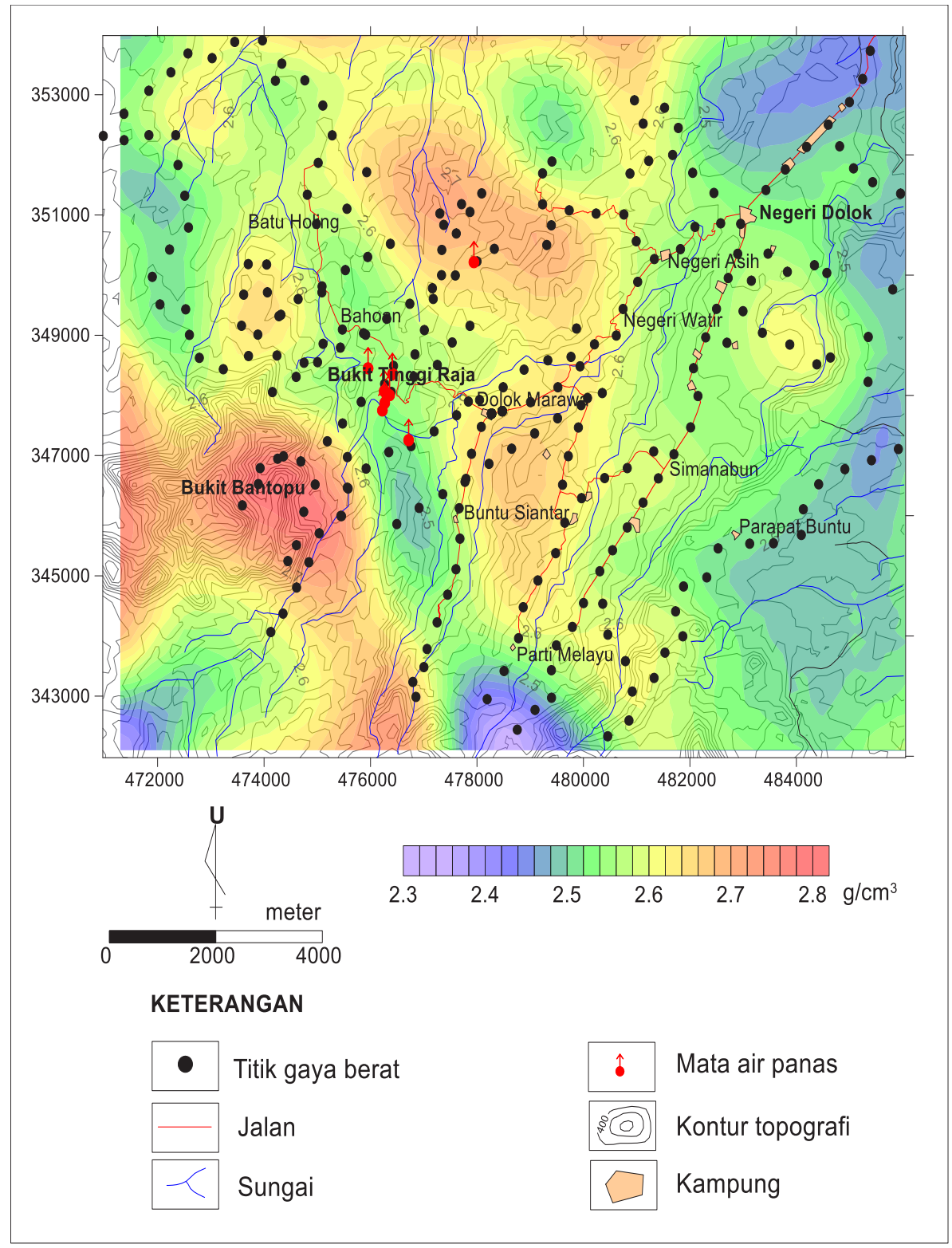

Gambar 10. Peta sebaran densitas elevasi -550 m daerah Dolok Marawa 


\section{MAKALAH ILMIAH}

Peta sebaran densitas pada elevasi $550 \mathrm{~m}$ (Gambar 10) memiliki pola yang sama dengan peta sebaran densitas pada elevasi $50 \mathrm{~m}$. Perbedaan terlihat dari sebaran densitas tinggi yang semakin meluas dan sebaran densitas rendah yang cenderung menyempit. Hal ini menggambarkan bahwa semakin ke dalam tingkat kekompakan batuan semakin tinggi sehingga nilai densitas batuan tersebut semakin tinggi. Keberadaan struktur juga terlihat dengan adanya kontras nilai densitas rendah dan tinggi yang membentuk kelurusan-kelurusan berarah baratlaut-tenggara dan baratdayatimurlaut.

Hasil pemodelan gaya berat 3D juga ditampilkan secara 3-dimensi dan ditumpangsusunkan dengan peta geologi
(Gambar 11). Gambar tersebut memperlihatkan batuan dengan densitas rendah tersebar di dekat permukaan, sedangkan batuan dengan densitas tinggi tersebar di bagian bawah. Di sekitar Dolok Bahtopu batuan dengan densitas tinggi terlihat muncul hingga ke permukaan yang diperkirakan berasosiasi dengan batuan andesit. Densitas rendah yang berada di sekitar sebaran mata air panas diperkirakan berasosiasi dengan zona rekahan yang menyebabkan densitas batuan menjadi lebih rendah dan memungkinkan batuan menjadi permeable. Zona tersebut sangat memungkinkan menjadi zona reservoar panas bumi. Di sebelah timur terdapat batuan dengan densitas rendah yang diduga berasosiasi dengan piroklastik Toba (Tufa Toba).

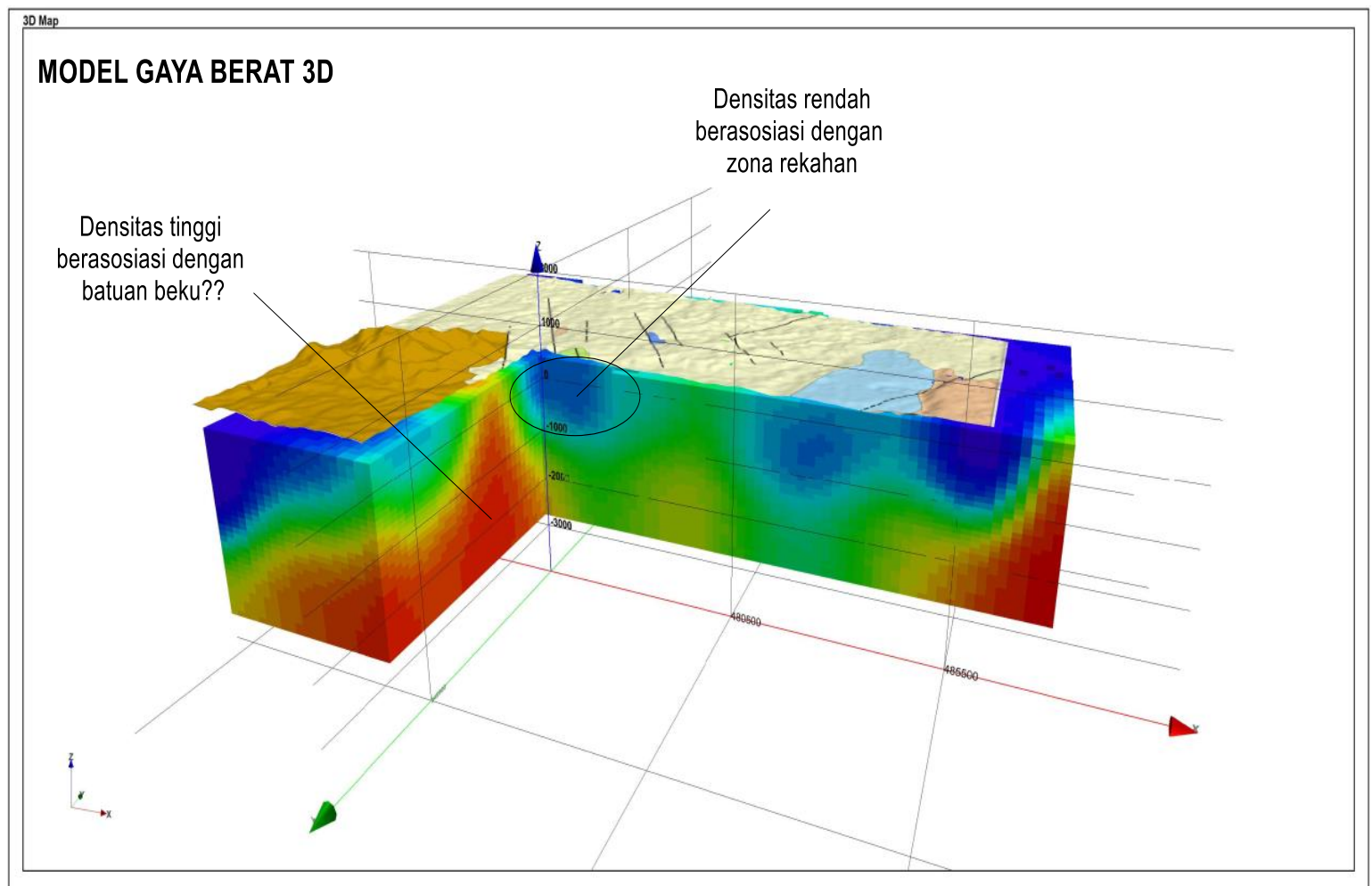

Gambar 11. Model gaya berat 3D yang ditampilkan secara 3-dimensi dan ditumpangsusunkan dengan peta geologi (Setiawan, dkk. 2006) 


\section{KESIMPULAN}

Pemodelan gaya berat 3D dapat memberikan gambaran mengenai distribusi densitas batuan di bawah permukaan baik secara lateral maupun horizontal. Hasil pemodelan gaya berat 3D di daerah panas bumi Dolok Marawa memperlihatkan adanya distribusi densitas tinggi $>2,7 \mathrm{~g} / \mathrm{cm}^{3}$ di sekitar Dolok Bahtopu yang menerus hingga ke bawah. Batuan dengan densitas tinggi tersebut diinterpretasikan sebagai respon dari tubuh andesit Dolok Bahtopu dan menjadi indikasi adanya sumber panas di bawah permukaan. Di sekitar manifestasi panas bumi, terdapat distribusi nilai densitas rendah yang diinterpretasikan sebagai zona rekahan dan memungkinkan batuan menjadi permeabel. Kontras nilai densitas tinggi dan rendah mengindikasikan adanya struktur sesar yang berarah baratlaut-tenggara. Struktur sesar tersebut menjadi batas dari zona rekahan yang berada di sekitar manifestasi panas bumi Tinggi Raja.

\section{UCAPAN TERIMA KASIH}

Penulis mengucapkan terima kasih yang sebesar-besarnya kepada Kepala Pusat Sumber Daya Geologi dan Koordinator Kelompok Penyelidikan Panas Bumi atas ijin penggunaan data dalam penulisan makalah ini. Penulis juga menyampaikan apresiasi yang setinggi-tinggi kepada rekan-rekan anggota tim survei gaya berat di daerah Dolok Marawa, dan rekan-rekan yang telah banyak membantu dalam penulisan makalah ini.

\section{DAFTAR PUSTAKA}

Anonim, 2015, Peta Sebaran Potensi Panas Bumi Indonesia, Badan Geologi, Bandung

Constable, S.C., Parker, R.L., Constable, C.G., 1987, Occam's Inversion : A Practical Algorithm for Generating Smooth Models from Electromagnetic
Sounding Data. Geophysics, Vol. 52, No. 3, pp.289-300.

Grandis, H., 2009, Pengantar Pemodelan Inversi Geofisika, Himpunan Ahli Geofisika Indonesia (HAGI), Jakarta.

Hjelt, S. E., 1992, Pragmatic Inversion of Geophysical Data. Springer-Verlag, Germany, pp. 262

Pirttijärvi, M. ,2004, GRABLOX: Gravity Interpretation and Modelling Software Based on 3D Block Model. User's guide. Archive Report, Q 16.2/2004/2, Geological Survey of Finland, pp. 39.

Santos, P.A., and Rivas, J.A., 2009, Gravity Survey Contribution to Geothermal Exploration in El Savador: The Cases of Berlin, Ahuachapan and San Vicente Areas, United Nations University, Geothermal Training Programme.

Setiawan, D.I., Setiadarma, D., Sundhoro, H., Sulaeman, B., 2006, Penyelidikan Geologi dan Geokimia di Daerah Panas Bumi Dolok Marawa, Kabupaten Simalungun, Sumatera Utara, Proceeding Pemaparan HasilHasil Kegiatan Lapangan dan Non Lapangan Tahun 2006 Pusat Sumber Daya Geologi.

Sundhoro, H., Bakrun, Suryakusuma, D., Sulaeman, B., Situmorang T., 2006, Survei Panas Bumi Terpadu (Geologi, Geokimia, dan Geofisika) Daerah Dolok Marawa, Kabupaten Simalungun, Sumatera Utara, Proceeding Pemaparan Hasil-Hasil Kegiatan Lapangan dan Non Lapangan Tahun 2006 Pusat Sumber Daya Geologi.

Suryakusuma, D., Situmorang D., Sumarna, Sunarto, Hasanudin, 2006, Penyelidikan Gaya Berat dan Geomagnet Daerah Panas Bumi Dolok Marawa Kabupaten Simalungun, 


\section{MAKALAH ILMIAH}

Propinsi Sumatera Utara, Proceeding Pemaparan Hasil-Hasil Kegiatan Lapangan dan Non Lapangan Tahun 2006 Pusat Sumber Daya Geologi.

Tripp, A., Moore, J., Ussher, G., McCulloch, J., 2002, Gravity Modeling of the Karaha-Telaga Bodas Geothermal System, Indonesia, Proceedings, Twenty-Seventh Workshop on
Geothermal Reservoir Engineering, Stanford University.

Zarkasyi, A., Bakrun, Widodo, S., 2006, Penyelidikan Geolistrik Daerah Panas Bumi Dolok Marawa, Kabupaten Simalungun, Provinsi Sumatera Utara, Proceeding Pemaparan Hasil-Hasil Kegiatan Lapangan dan Non Lapangan Tahun 2006 Pusat Sumber Daya Geologi.

\begin{tabular}{ll}
\hline Diterima & $:$ 5 Juni 2015 \\
Direvisi & $:$ 23 Juli 2015 \\
Disetujui & $: 26$ Agustus 2015
\end{tabular}

